\title{
The LIM domain-containing homeo box gene Xlim-1 is expressed specifically in the organizer region of Xenopus gastrula embryos
}

\author{
Masanori Taira, ${ }^{1,2}$ Milan Jamrich, ${ }^{3}$ Peter J. Good, ${ }^{1}$ and Igor B. Dawid ${ }^{1}$ \\ ${ }^{1}$ Laboratory of Molecular Genetics, National Institute of Child Health and Human Development, National Institutes \\ of Health, Bethesda, Maryland 20852 USA; ${ }^{2}$ Department of Biochemistry, Chiba University School of Medicine, Chiba \\ 280, Japan; ${ }^{3}$ Laboratory of Molecular Pharmacology, Center for Biologics Evaluation and Research, Food and Drug \\ Administration, Bethesda, MD 20852 USA
}

\begin{abstract}
A novel cysteine-rich motif, named LIM, has been identified in the homeo box genes lin-11, Isl-1, and mec-3; the mec-3 and lin-11 genes determine cell lineages in Caenorhabditis elegans. We isolated LIM class homeo box genes from Xenopus laevis that are closely related to lin-11 and mec-3 in the LIM and homeo domains. This paper deals with one of these genes, Xlim-1. Xlim-1 mRNA is found at low abundance in the unfertilized egg, has a major expression phase at the gastrula stage, decreases, and rises again during the tadpole stage. In adult tissues the brain shows the highest abundance, by far, of Xlim-1 mRNA. The maternal and late expression phases of the Xlim-1 gene suggest that it has multiple functions at different stages of the Xenopus life cycle. In the gastrula embryo, Xlim-1 mRNA is localized in the dorsal lip and the dorsal mesoderm, that is, in the region of Spemann's organizer. Explant experiments showed that Xlim-1 mRNA is induced by the mesoderm-inducer activin $A$ and by retinoic acid, which is not a mesoderm inducer but affects patterning during Xenopus embryogenesis; application of activin $A$ and retinoic acid together results in synergistic induction. The structure, inducibility, and localized expression in the organizer of the Xlim-1 gene suggest that it has a role in establishing body pattern during gastrulation.
\end{abstract}

[Key Words: Xenopus laevis; homeo box genes; LIM domain; Xlim-1; organizer; activin A; retinoic acid]

Received November 5, 1991; revised version accepted January 7, 1992.

The basic body plan of the vertebrate embryo is established in early development as a result of a series of cell interactions that lead to the differentiation of the mesoderm and the elaboration of the dorsoventral and anteroposterior axes. As studied in the amphibian embryo, two early inductive events can be distinguished that are responsible for mesoderm and neural differentiation (for review, see Smith 1989; Dawid et al. 1990; Melton 1991). During cleavage and blastula stages, a signal or set of signals from the vegetal hemisphere specifies the equatorial or marginal zone as mesoderm, simultaneously establishing dorsoventral polarity in the embryo. Overt dorsal development is first signaled by the appearance of the dorsal lip, a region known as the organizer because of its profound inducing ability that generates a complete secondary axis when transplanted to the ventral side of a host embryo (Spemann and Mangold 1924; see reviews cited above). During gastrulation, dorsal mesoderm moving from the region of the dorsal lip along the blastocoel roof toward the animal pole induces the neural plate, with its anteroposterior polarity being established in this process. Multiple signals from the mesoderm are be- lieved to be involved in patterning the neural plate along the anteroposterior axis (Mangold 1933; Sharpe and Gurdon 1990).

The molecular basis of embryonic induction and pattern formation in the amphibian embryo is not fully understood, but at least two peptide growth factors appear to be involved in mesoderm induction, fibroblast growth factor (FGF) (Kimelman and Kirschner 1987; Slack et al. 1987) and activin (Asashima et al. 1990; Smith et al. 1990; Thomsen et al. 1990|. These factors exert multiple effects on responsive cells, one important effect being the control of gene expression. In particular, the very rapid activation of regulatory genes by mesoderm-inducing factors is likely to be an important step in the hierarchy of events that leads from factor action to tissue differentiation and pattern formation (for review, see Dawid et al. 1990; De Robertis 1990, 1991; Melton 1991). The earliest known response gene for activin in frog embryo explants is the homeo box gene Mix.1; during normal embryogenesis, this gene is expressed only for a few hours in late blastula and gastrula stages, and its mRNA is localized in the vegetal hemisphere, the region of the 
future endoderm and mesoderm (Rosa 1989). Two other homeo box genes, Xhox 3 and XlHbox 6, which are induced somewhat later in animal explants by inducing factors (Ruiz i Altaba and Melton 1989a; Cho and De Robertis 1990), have been shown to be involved in posterior development of the embryo (Ruiz i Altaba and Melton 1989b; Cho et al. 1991).

The work mentioned above, which implicated homeo box genes as potential regulators of pattern formation in amphibian development, complements extensive studies in other organisms including vertebrates (De Robertis et al. 1990; Lonai and Orr-Urtreger 1990; Kessel and Gruss 1990; Wilkinson and Krumlauf 1990). More than 80 homeo box genes have been isolated and classified into several subfamilies by amino acid sequence relationships (Scott et al. 1989). In some subclasses of homeo box genes a second conserved domain is associated with the homeo domain. It has been shown for both the POU class (Herr et al. 1988) and the paired class (Bopp et al. 1986) that the second conserved domain participates directly in DNA binding (Ruvkun and Finney 1991; Treisman et al. 1991). Recently, a new class of homeo box genes was identified, which consists of the Caenorhabditis elegans genes mec-3 (Way and Chalfie 1988) and lin-11 (Freyd et al. 1990), and a rat gene, Isl-1 (Karlsson et al. 1990). These three genes have two tandemly repeated cysteine-histidine motifs, referred to as LIM domains, in addition to a homeo box that once belonged to the "unclassified group" (Scott et al. 1989). mec-3 and lin-11 are involved in determination of cell lineage, specifying mechanosensory neurons and a vulval precursor cell, respectively. IsI-1 encodes an insulin gene enhancer-binding protein and is expressed in developing and mature islet cells, implying a role in islet cell determination.

To examine whether members of this class of homeo box genes are involved in vertebrate embryogenesis, we isolated LIM domain-containing homeo box genes from Xenopus laevis. In this paper we describe some properties of the Xlim-1 gene that is similar in the homeo box and LIM domains to $1 \mathrm{in}-11$. Xlim-1 is activated by the mesoderm-inducer activin $\mathrm{A}$ and by retinoic acid in animal explants from blastula embryos. In the gastrula embryo, Xlim-1 RNA is specifically expressed in the dorsal lip and in the dorsal mesoderm, as it extends anteriorly. These properties suggest that Xlim-1 is involved in the establishment of the body plan during gastrulation in $X$. laevis embryos.

\section{Results}

\section{Isolation and sequence of the Xlim-1 gene}

Isolation of LIM class homeo box genes from Xenopus was attempted by the polymerase chain reaction (PCR) with a variety of primer pairs and DNA from embryonic cDNA libraries as template. Degenerate oligonucleotide primer pairs were designed on the basis of sequences conserved among the LIM class homeo domains of mec-3 (Way and Chalfie 1988), lin-11 (Freyd et al. 1990), Isl-1 (Karlsson et al. 1990), and another C. elegans LIM-con- taining homeo box gene, ceh-14 (see Materials and methods; Bürglin et al. 1989; T.R. Bürglin and G. Ruvkun, pers. comm.). We did not succeed in generating the desired PCR products when using primer pairs based on conserved residues of the LIM domains, or with LIM domain primers together with a homeo box primer, presumably because the LIM motif represents rather few and dispersed conserved amino acids. The two primers corresponding to the RGPRTTI and WFQNRRSKE sequences in the homeo domain (primers A and B in Fig. $1 C$ ) yielded the expected band of $0.18 \mathrm{~kb}$. This band was isolated and cloned into a plasmid vector, and 200 clones were sorted into groups by their hybridization intensity with the PCR product, and by cross-hybridization (see Materials and methods|. One sequence class, including PCR clone 28 , accounted for $>90 \%$ of all clones and was named Xlim-1 (Fig. 1A). Sequence analysis revealed that $X I i m-1$ and a minor class named Xlim-2 (clones 30 and 152) are closely related to lin-11. Xlim-2A and Xlim-2B, which show $97 \%$ nucleotide sequence identity, probably correspond to the two copies of the same gene occurring because of the apparent pseudotetraploid nature of $X$. laevis (Thiébaud and Fischberg 1977). Although the deduced 39-amino-acid sequence (between the PCR primers) of Xlim-1 is the same as that of Xlim-2B and shows only one difference to $X$ lim- $2 A$, the nucleotide sequences show only $72 \%$ identity, suggesting that Xlim-1 and Xlim-2 are different genes. A third sequence class (clone 171), named Xlim-3, is more homologous to lin-11 and ceh-14 than to other reported homeo domain proteins. Thus, three distinct clones were identified as candidates of LIM-containing homeo box genes in Xenopus. The properties of Xlim-2 and Xlim-3 will be described elsewhere.

The sequence of long Xlim-1 cDNA clones predicts a protein of 403 amino acids that contains LIM1 and LIM2 domains in addition to the homeo domain (Fig. 1B). Xlim-1 has a very short protein sequence before the LIM1 domain, and linkers between LIM1 and LIM2 and between LIM2 and the homeo domain that are similar in length, but not in sequence, to those of mec-3, lin-11, and Isl-1 (Way and Chalfie 1988; Freyd et al. 1990; Karlsson et al. 1990). The carboxy-terminal region of Xlim-1 is longer than that of other known LIM domain genes and is rich in proline $(16 \%)$, glycine $(10 \%)$, and serine $(13 \%)$. This proline-rich carboxy-terminal region of Xlim-1 is similar in composition but not in sequence to that of lin-11 (17\% proline).

The amino acid sequences of the LIM and homeo domains of Xlim-1 were aligned with those of other LIM class homeo box genes and with rhombotin (McGuire et al. 1989; Boehm et al. 1990), a gene that contains two LIM domains but no homeo domain. Figure $1 \mathrm{C}$ shows that the LIM1 domain has two and the LIM2 domain has four conserved residues in addition to the consensus cysteine and histidine residues that define the LIM motif. The LIM domains of Xlim-1 show $37-54 \%$ sequence identities to the LIM domains of the other genes listed in Figure 1C. Two additional LIM domain-containing genes, CRIP (Birkenmeier and Gordon 1986) and hCRP 
Taira et al.

PCR
Clones
$\quad \# 28$
$\# 30$
$\# 152$
$\# 171$

1 $\begin{array}{llllllllllllllllllll}K & A & K & Q & L & E & T & L & K & A & A & F & A & A & T & P & K & P & T & R\end{array}$ CAAAGCCAAACAGTTGGAGACGCTGAAAGCAGCATTTGCAGCTACACCAAAACCGACCCGA T..G....G..AC........T..G.T..T..ATT..C..C.T.G.....A..

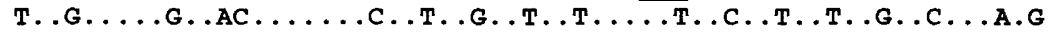
C.СT..A...............AAT..C.A..ACAACT.T...........

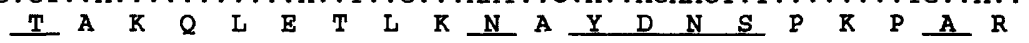

(1)

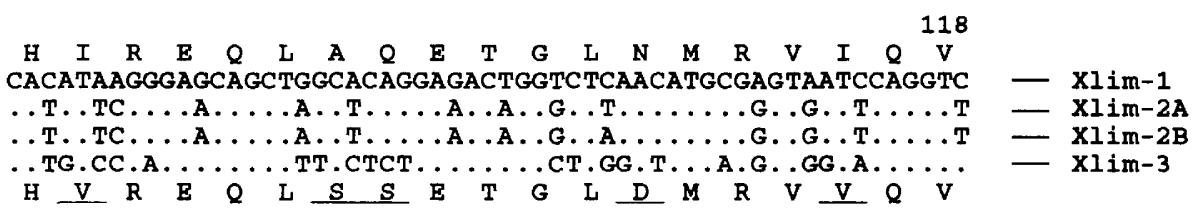

TCTAGACCACAGTGTCTGCCTTCTATTCTCCTAATCCGCCCATTCCTCTAAAATCCCAAATAACCAAAGGCAAT

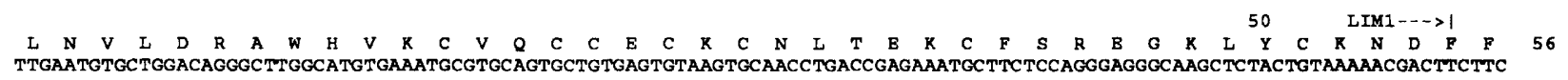

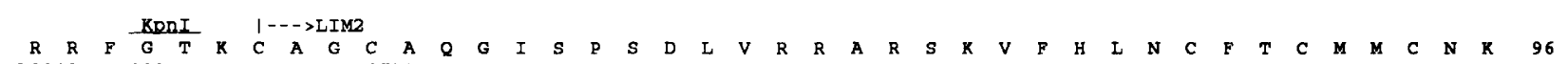
AGGCGCTTTGGTACCAAGTGTGCGGGCTGTGCCCAGGGGATCTCCCCCAGTGACCTAGTCAGGAGGGCAAGGAGCAAAGTGTTCCACTTGAACTGTTTCACCTGCATGATGTGTAACAAA

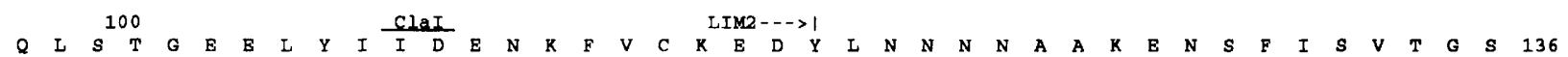
CAGCTCTCCACTGGAGAGGACTTTATATAATCGATGAGAACAAGTTCGTCTGCAAAGAAGATTACTTAAACAACAACAACGCTGCCAAAGAAAACAGCTTTATCTCAGTAACAGGCAGT

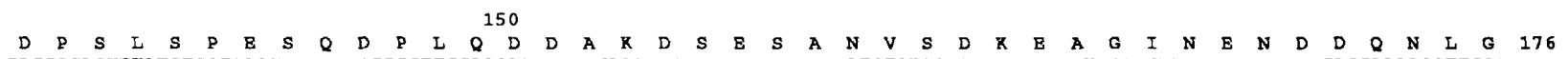
GACCCCAGTT'ATCTCCTGAATCTCAAGACCCGTTGCAAGATGACGCTAAAGACTCTGAAAGTGCCAATGTCTCTGATAAGGAGGCTGGGATTAATGAAAACGACGACCAAAACCTTGGG

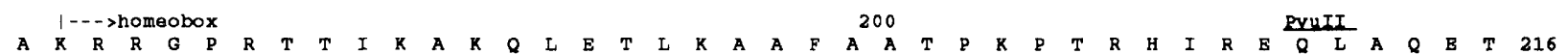
GCGAAAAGAAGGGGACCTAGGACCACTATCAAAGCCAAACAGTTGGAGACGCTGAAAGCAGCATTTGCAGCTACACCAAAACCGACCCGACACATAAGGGAGCAGCTGOCACAGGAGACT

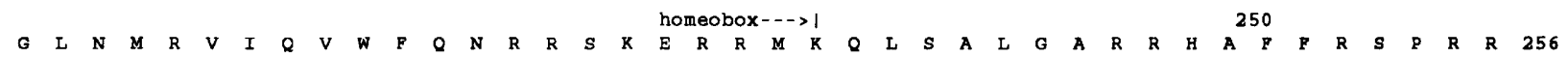
GGTCTCAACATGCGAGTAATCCAGGTCTGGTTCCAGAACCGACGATCCAAAGAGAGAAGAATGAAACAGCTGAGCGCTCTGGGAGCCCGGAGACACGCCTTCTTCCOCAGCCCCCGAAGG

$\begin{array}{lllllllllllllllllllllllllllllllllllllllllllllllll}M & R & P & L & V & D & R & L & E & P & G & E & L & I & P & N & G & P & F & A & F & Y & G & D & Y & Q & S & E & Y & Y & G & P & G & S & N & Y & D & F & F & P & 296\end{array}$

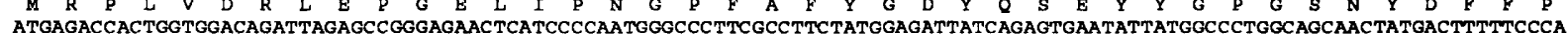

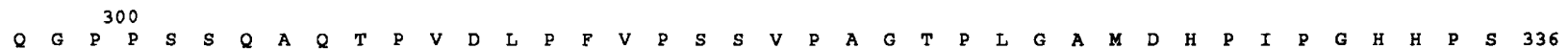
CAAGGACCCCCATCGTCTCAAGCTCAGACTCCTGTAGATTTGCCATTTGTACCTTCCTCTGTGCCCGCAGGAACTCCCCTTGGTGCAATGGATCACCCGATCCCCGOACACCACCCATCT

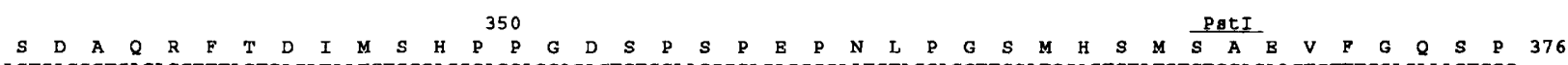
AGTGACGCTCAGAGGTTTACTGACATAATGTCCCACCCACCAGGAGACTCTCCAAGCCCAGAGCCCAATCTACCAGGTTCCATGCACTCTATGTCTGCAGAAGTGTTTGGACAAAGTCCC

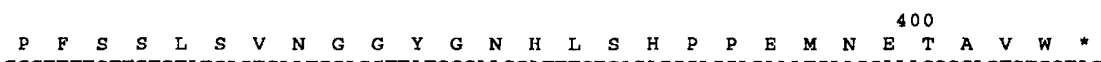

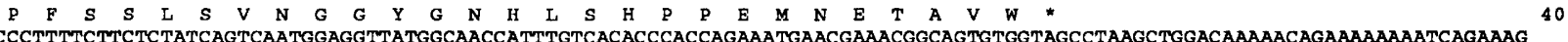

GACTGGgTACAATgGGTTACCATGTAAAgGTTTCCTATGAAAATAAC

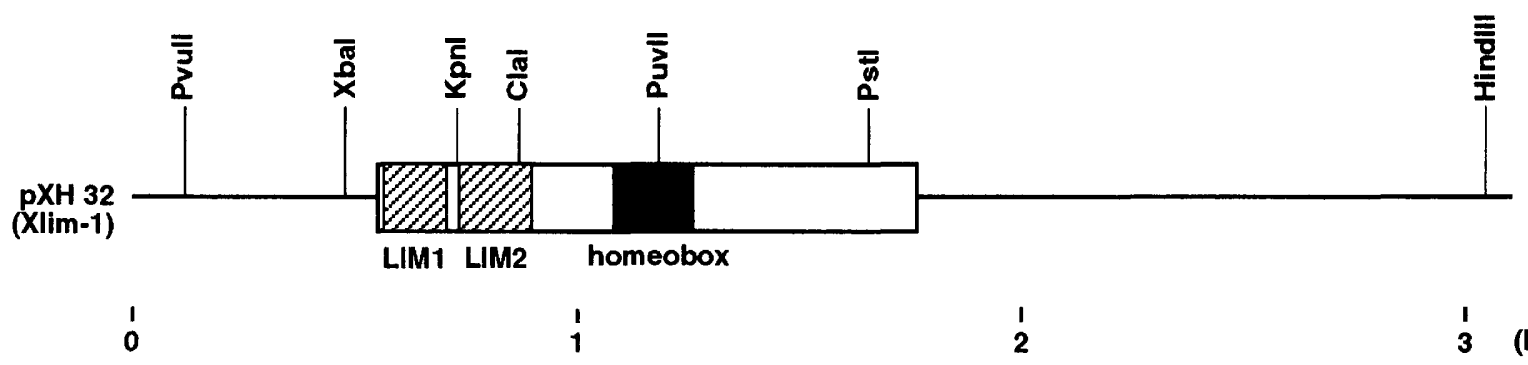

(kb)

Figure 1. (Continued on facing page.) 
(Liebhaber et al. 1990), show lower sequence similarity with Xlim-1. In the homeo domain, homology between Xlim-1 and lin-11 is high (59 of 61 residues identical). As homeo domains are known to be involved in sequencespecific DNA binding and gene regulation, the target sequences of Xlim-1 may be closely related to those of lin-11.

\section{Developmental expression of the Xlim-1 gene}

The developmental expression of the Xlim-1 gene is shown in Figure 2A. Minor RNA bands that appear at different stages are likely to be encoded by the Xlim-1 gene, as the Xlim-2 gene shows only a $72 \%$ sequence identity in the homeo box region, which is likely to be the most similar region of the two genes. At this level of homology, no cross-hybridization would be expected under the conditions used. A low-abundance maternal transcript of $2.7 \mathrm{~kb}$ persists to the gastrula stage and then disappears. We do not know how this transcript relates to the major zygotic RNA represented by the sequence in Figure 1B. The major embryonic transcript of $3.4 \mathrm{~kb}$ appears at the early gastrula stage, implying that the $X \mathrm{Iim}-1$ gene is activated during embryogenesis at or very shortly after the midblastula transition (Newport and Kirschner 1982). Xlim-1 RNA accumulation peaks at late gastrula to early neurula stages, and decreases and rises again in the tadpole. As is discussed below, these two periods of RNA accumulation correspond to periods of distinct spatial regulation of Xlim-1 expression.

In adult frog tissues Xlim-1 RNA is present primarily in the brain in the form of the major zygotic 3.4-kb species (Fig. 2B). Lower levels of this RNA are seen in the eye and the kidney, and the ovary contains the $2.7-\mathrm{kb}$ maternal RNA. Testis appears to express a more complex set of smaller RNAs. Although we have not analyzed further the Xlim-1 transcripts in the testis we know that this RNA sample was intact based on its hybridization with a different gene, the $\beta_{1}$-subunit of $\mathrm{Na}, \mathrm{K}$ ATPase (see Good et al. 1990). Lung, muscle, and skin (Fig. 2B), and heart, liver, stomach, pancreas, and spleen (data not shown) contained no detectable Xlim-1 mRNA.

\section{Spatial distribution of Xlim-1 expression in the embryo}

To examine the localization of Xlim-1 RNA, embryos at stage 11 (gastrula) were dissected and analyzed by Northern blots. Figure 3 shows that Xlim-1 mRNA was present predominantly in the vegetal (endoderm and mesoderm) and dorsal halves (lanes 2,4 ), and at low levels in animal (ectodermal) and ventral halves (lanes 1,3 ). For compar-

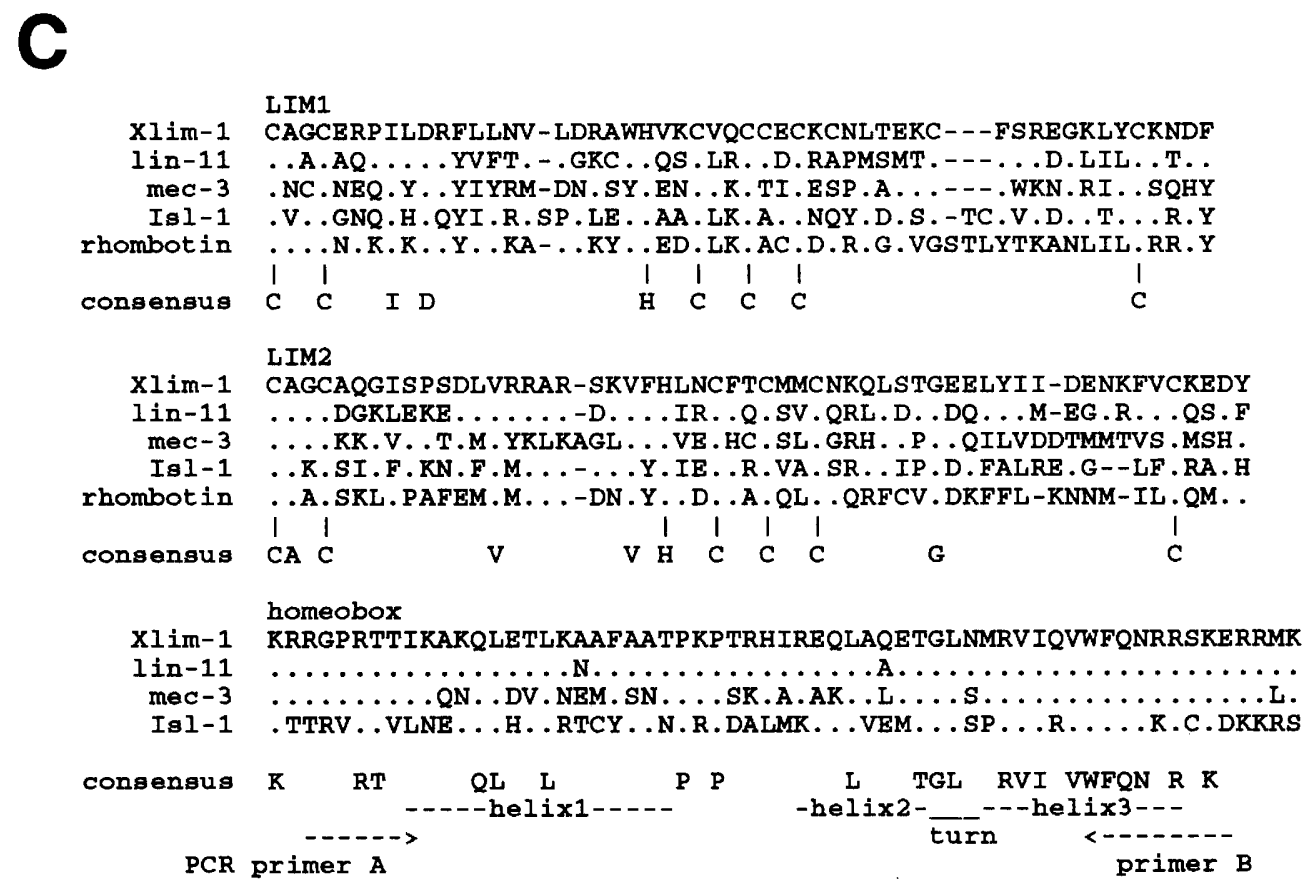

Figure 1. (A) Nucleotide sequences of PCR products obtained as described in Materials and methods. The predicted amino acid sequence of Xlim-1 and Xlim-2B, which is identical, is shown at the top; that of Xlim-3 is at the bottom. Underlining indicates amino acids that are different from Xlim-1. Xlim-2A has a single-amino-acid difference, isoleucine (ATT codon), which is also underlined. Dots indicate identical nucleotides. The GenBank/EMBL accession numbers for sequences of PCR clones 30,152 , and 171 are Z11587, Z11588, and Z11589, respectively. $(B)$ Nucleotide and predicted amino acid sequence of Xlim-1. Amino acids are in the single-letter code. Asterisks denote in-frame stop codons. Below the sequence the general structure of the cDNA clone, pXH32, is illustrated. The GenBank/EMBL accession number is X63889. (C) Comparison of LIM1, LIM2, and homeo box domains of Xlim-1, lin-11 (Freyd et al. 1990), mec-3 (Way and Chalfie 1988), Isl-1 (Karlsson et al. 1990), and rhombotin (McGuire et al. 1989; Boehm et al. 1990). Identities are indicated by dots; spaces inserted for alignment, by dashes. The consensus LIM motif is shown by vertical bars. The positions of helix 1-3 and the turn are indicated in the homeo domain (Scott et al. 1989). PCR primers A and B are shown by arrows. 
A
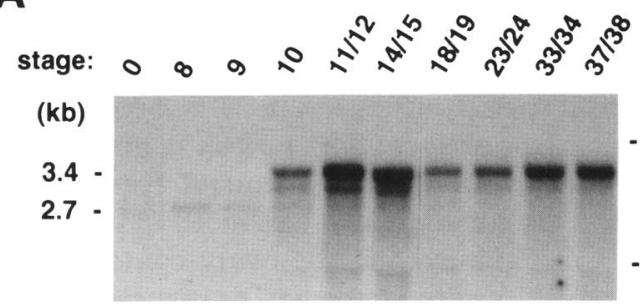

B

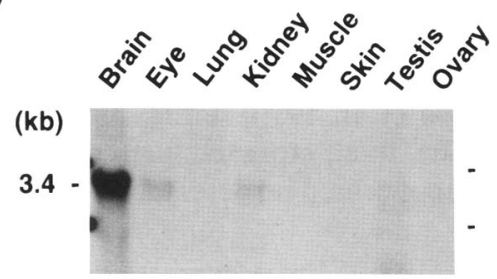

Figure 2. $|A|$ Developmental expression of Xlim-1. Total RNA samples $(7.5 \mu \mathrm{g}$ ) from stages 0 (unfertilized egg), 8 (early blastula), 9 (late blastula), 10 (initial gastrula), 11/12 (late gastrula), 14/15 (neural plate stage), 18/19 (neural tube stage), 23/24 (tail bud stage), 33/34 (early tadpole), and $37 / 38$ (tadpole) were separated on a gel, blotted, and hybridized with an Xlim-1 probe (see Materials and methods). The positions of $18 \mathrm{~S}$ and $28 \mathrm{~S}$ rRNAs are indicated at right. (B) Tissue distribution of Xlim-1 mRNA in adult Xenopus. Ten micrograms of total RNA was loaded onto each lane. Staining of the gel with ethidium bromide verified that closely similar amounts of RNA were loaded onto each lane.

ison, the same blots were probed with the homeo box gene Mix.1 (Rosa 1989) and the elongation factor gene $E F-1 \alpha$ (Krieg et al. 1989). Mix.1 mRNA was expressed predominantly in the vegetal half without any dorsoventral difference, as reported previously on the basis of in situ hybridization (Rosa 1989). EF-1 $\alpha$ hybridization showed that similar amounts of RNA were loaded in each lane.

More precise localization of Xlim-1 RNA was achieved by whole-mount in situ hybridization (Hemmati-Brivanlou et al. 1990; Harland 1991). In the early period of the midgastrula (stage 11), Xlim-1 RNA is concentrated at the dorsal lip and immediately above it in the dorsal mesoderm, as seen in Figure $4 \mathrm{~A}$; here the embryo is photographed from a lateral direction with the focal plane at the center of the embryo. Figure 4A land also the similar Figure 4C) show that Xlim-1 expression is absent from the dorsal ectoderm (superficial layer); this conclusion was supported by detailed inspection of several stained gastrula-stage embryos. The same embryo photographed from a dorsovegetal viewpoint shows that the domain of intense Xlim-1 expression is narrow vegetally at the dorsal lip and expands somewhat laterally in the area above it (Fig. 4B). In addition to this intense domain of expression a lower level of Xlim-1 RNA appears to extend laterally from the dorsal lip and may form a belt around the entire embryo. Although it is difficult to be certain that this low level of staining is significant, it may corre- spond to the small but definite fraction of Xlim-1 RNA seen in the ventral hemisphere of dissected embryos by Northern blotting (see Fig. 3). Sense strand control hybridization did not show this or any specific staining. Sense strand sometimes produced diffuse light staining in cavities, as seen at the top left of the blastocoel in Figure $4 C$; such diffuse pigment deposition is therefore nonspecific.

As gastrulation proceeds, the dorsal mesoderm extends along the blastocoel roof toward the animal pole and the future anterior end of the embryo; concomitantly, the expression of Xlim-1 moves anteriorly (Fig. 4C,D). Although Xlim-1 mRNA is still present at the region of the dorsal lip, its highest level is reached in an area close to the anterior tip of the advancing mesoderm, as seen most clearly in Figure 4D. Expression is limited to a narrow region at the dorsal side of the embryo, and very little Xlim-1 RNA is present elsewhere in the embryo at the mid- to late gastrula stage (Fig. 4C,D). During later development the Xlim-1 gene is expressed in several tissues, for example, in adult frogs where brain and, to a lesser extent, kidney and eye, contain Xlim-1 mRNA (see Fig. 2B). These tissues also express Xlim-1 mRNA during tadpole stages of development (M. Taira, M. Jamrich, H. Otari, and I.B. Dawid, unpubl.). This later expression in different tissues, especially the nervous system, represents a distinct phase of expression from that during gastrulation, as reflected in the rise, fall, and second rise in the quantity of Xlim-1 RNA (see Fig. 2A). It is likely that different regulatory influences control the early and late phases of Xlim-1 gene expression in Xenopus.

Activation of Xlim-1 gene expression by activin $A$ and retinoic acid

Because Xlim-1 RNA is not significantly expressed in the ectodermal region of the gastrula but is expressed in

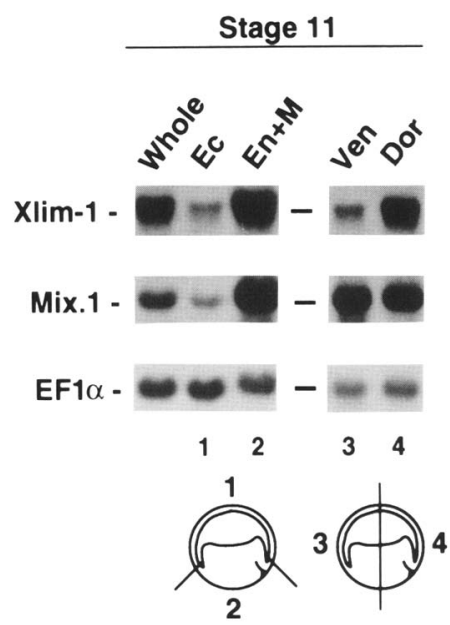

Figure 3. Spatial distribution of Xlim-1 mRNA in gastrula embryos. Stage 11 Xenopus embryos were dissected into ectoderm (Ec) and endoderm plus mesoderm $(\mathrm{En}+\mathrm{M})$, or into ventral (Ven) and dorsal (Dor) halves. Ten micrograms of total RNA was applied on each lane. Mix.1 and EF-1 $\alpha$ were analyzed for comparison (see text). 

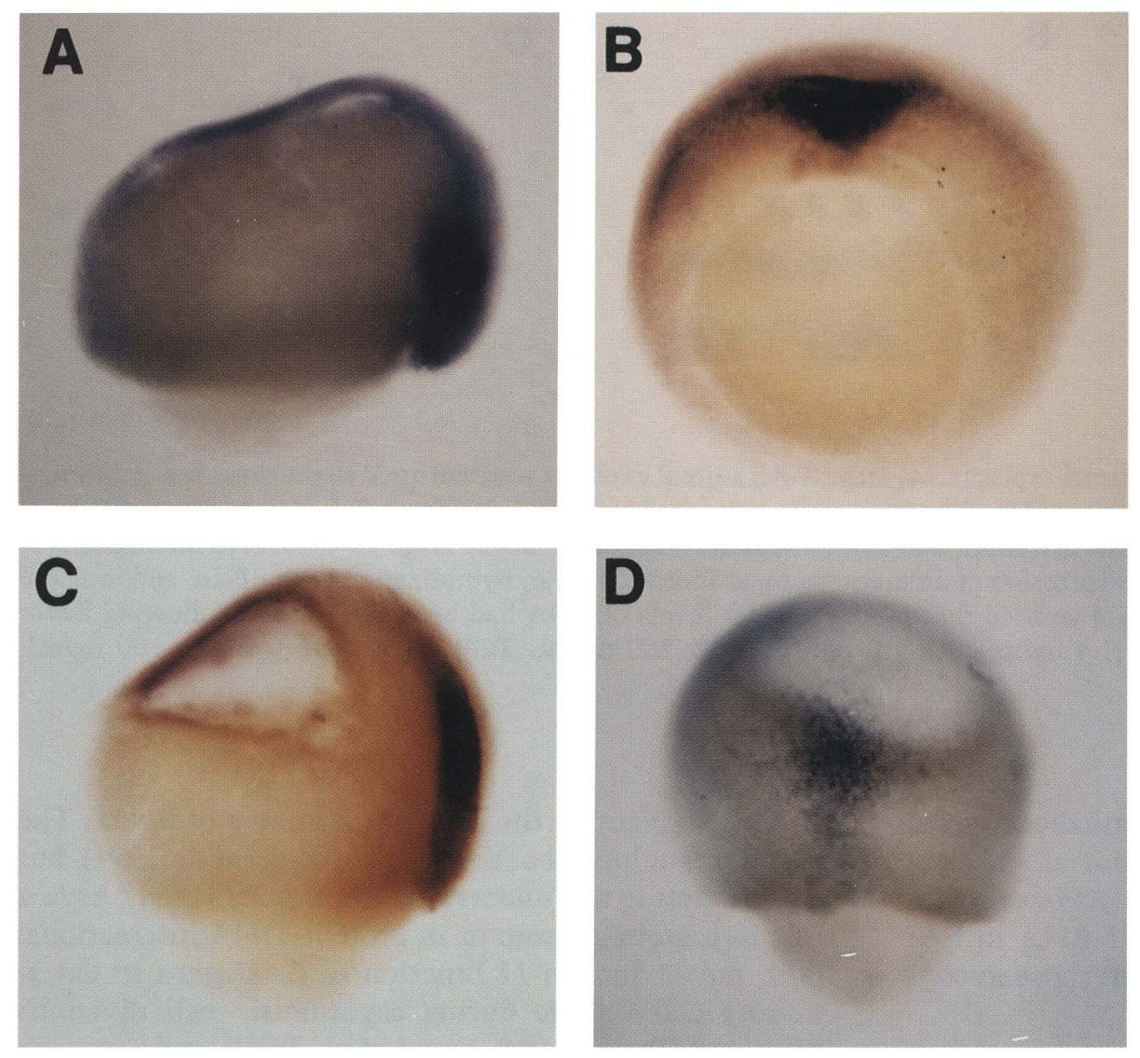

Figure 4. Spatial distribution of Xlim-1 mRNA in the gastrula as visualized by whole-mount in situ hybridization (see Materials and methods). $A$ and $B$ show the same stage 11 embryo. $A$ is photographed from a lateral viewpoint, with the focal plane at the center of the embryo; animal at the top and dorsal on the right. The blastocoel has largely collapsed during preparation. $B$ shows a vegetal view tilted slightly dorsally; dorsal is at the top. In this early midgastrula embryo the mesoderm has involuted only a short distance from the dorsal lip. Xlim-1 is expressed at the dorsal lip and in a fan-like widening at the anterior margin of the mesoderm. $C$ and $D$ show a slightly older embryo at stage 11.5 , with animal at the top. The mesoderm has migrated farther toward the animal pole, as seen in the lateral view in $C$; dorsal is at the right. The dorsal view in $D$ shows that the highest Xlim-1 expression is now located in the anterior region of the dorsal mesoderm, which will shortly form the prechordal plate. dorsal mesoderm, we tested whether this gene could be activated in animal explants by mesoderm inducers. Activin A, known to be a strong inducer of dorsal mesoderm (Asashima et al. 1990; Smith et al. 1990; Thomsen et al. 1990), elicited the accumulation of Xlim-1 RNA in such explants, whereas TGF- $\beta 2$ and TGF- $\beta 3$, less powerful mesoderm inducers (Rosa et al. 1988; Roberts et al. 1990), did not (Fig. 5A). Retinoic acid (RA) is not a mesoderm inducer but has various effects on Xenopus embryos as is explored in the Discussion. There has been no report of gene activation by RA alone in animal explants of blastula embryos, but RA treatment of whole embryos enhances the expression of several homeo box genes (Cho and De Robertis 1990; Sive and Cheng 1991). As shown in Figure 5A, RA elicited the accumulation of Xlim-1 RNA in such explants, and RA plus activin A had a definite synergistic effect. For comparison we hybridized the same RNA samples with a Mix.1 probe. Mix. 1 is strongly induced by activin A in agreement with earlier work that used XTC-MIF (Rosa 1989), which contains activin A as its major effective component (Smith et al. 1990). In contrast to Xlim-1, Mix.1 is not affected by RA either alone or in combination with activin. Figure $5 B$ shows that FGF does not induce the expression of XIim-1 and does not affect the induction by either activin $A$ or RA. The FGF-responsive gene 1A11 (Rosa and Dawid 1990) was used as a positive control in this experiment.

Mix.1 was identified as a gene rapidly induced by activin even in the presence of the protein synthesis inhib- itor cycloheximide (Rosa 1989). Figure 5C shows that Xlim-1 is likewise inducible by activin A in the presence of this inhibitor. In Figure 6A we compare the induction kinetics of Mix. 1 and Xlim-1 by activin A: Both mRNAs accumulate rapidly, but $\mathrm{Mix} .1$ appears to lead and peaks at $3 \mathrm{hr}$ after induction, whereas Xlim-1 RNA lags slightly, reaching its highest level after $4 \mathrm{hr}$. RA induces Xlim-1 less rapidly than activin, with peak RNA accumulation after $7 \mathrm{hr}$ (Fig. 6B). When exposed to both factors, animal explants respond with kinetics that correspond to those for RA with a 7-hr peak but at a substantially higher level. The rise of Xlim-1 RNA in activininduced animal explants corresponds to that in the whole embryo (see Fig. 2A) and in vegetal halves (data not shown), but the reduction of the RNA in explants treated with activin alone is faster than in the embryo. Eleven hours after induction animal explants do not contain detectable levels of Xlim-1 RNA (Fig. 6A) in contrast with whole embryos of comparable age, that is, about stage 17 (see Fig. 2A). Thus, Xlim-1 expression in the embryo after the midgastrula stage may depend on RA.

Exposure of whole Xenopus embryos to RA leads in a concentration-dependent manner to anterior malformations as in microcephaly (Durston et al. 1989). Although no gross effects on development are apparent in the blastula and gastrula stages, a ventralizing effect on explanted mesoderm has been observed (Ruiz i Altaba and Jessel 1991a). RA-treated gastrula embryos, as with activin-induced animal caps, respond to RA by enhanced 
A

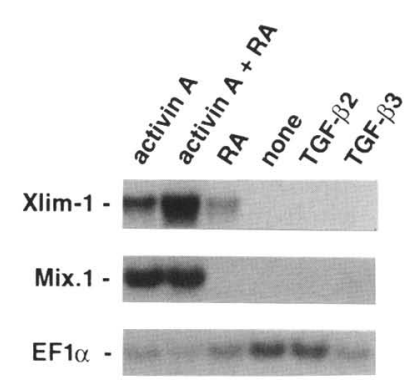

B

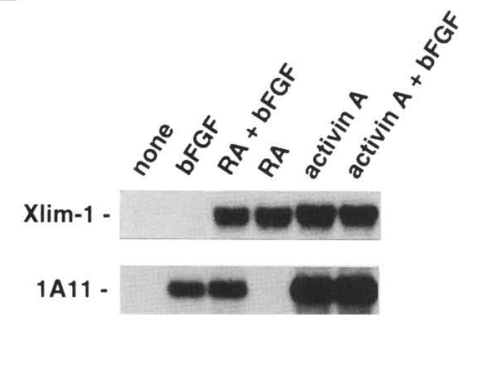

C

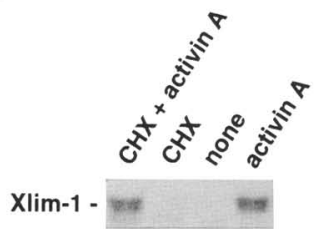

Figure 5. Induction of Xlim-1 expression in animal explants. (A) Stage 8-8.5 animal explants were cultured in the presence of different factors for $4 \mathrm{hr}$. $(B)$ Stage 8-8.5 explants were cultured for $5 \mathrm{hr}$ until siblings reached stage 10.5. (C) Stage 9-9.5 animal explants were cultured for $30 \mathrm{~min}$ in $\mathrm{CHX}, 30 \mathrm{~min}$ in CHX plus activin A, and $2 \mathrm{hr}$ in activin A; siblings reached stage 10-10.5. Five micrograms of total RNA from each sample was analyzed for expression of different genes, as indicated. In $A$, hybridization with EF-1 $\alpha$, and in $B$ and $C$, staining with ethidium bromide (not shown) verified that closely similar levels of RNA had been loaded. The following factor concentrations were used: activin A, $50 \mathrm{pM}(1.4 \mathrm{ng} / \mathrm{ml}) ; \mathrm{RA}, 10 \mu \mathrm{M}$; TGF- $\beta 2,200 \mathrm{ng} / \mathrm{ml}$; TGF- $\beta 3,50 \mathrm{ng} / \mathrm{ml} ; \mathrm{bFGF}, 100 \mathrm{ng} / \mathrm{ml}$; cycloheximide (CHX), $5 \mu \mathrm{g} / \mathrm{ml}$.

expression of Xlim-1 RNA (Fig. 7). The enhancement is the result of overexpression in both the dorsal and ventral regions of the embryo (Fig. 7, bottom). At later stages of development the total levels of Xlim-1 RNA in RAtreated embryos are not very different from those in control embryos.

\section{Discussion}

The LIM class of homeo box genes in vertebrate development

We have identified three LIM class homeo box genes in a cDNA library derived from Xenopus embryo RNA, implying that multiple members of this subclass of genes are expressed in vertebrate embryos and have a role in developmental regulation in these animals. In this paper we describe some properties of one of these genes, named Xlim-1. Although the Xlim-1 gene is highly homologous to the lin-11 gene in the homeo domain, homology between the LIM domains of the two genes is only partial (Fig. 1C). In contrast, the rhombotin genes of human and Drosophila are highly conserved (Boehm et al. 1990), suggesting precise structural requirements for execution of the biological function of LIM domains; therefore,
Xlim-1 may not be the Xenopus homolog of lin-11. The LIM domain binds both zinc and iron (Li et al. 1991), but its function is not understood at present; it may have a role in protein-protein or in protein-DNA interactions. Both mec-3 and lin-11 function in C. elegans in determining cell lineage during asymmetric cell divisions (Way and Chalfie 1988; Freyd et al. 1990), and a similar type of function could be fulfilled by the Xlim-1 and additional LIM class homeo box genes in amphibian embryogenesis.

\section{The role of the dorsal lip and the dorsal mesoderm in gastrulation}

The ability of the dorsal lip to induce a secondary axis when transplanted into a host embryo has earned it the name "organizer" and much attention since the original work of Spemann and Mangold (1924). Yet it has become clear that organizer induction is not the first cell interaction in amphibian embryogenesis. During the cleavage and blastula stages, mesoderm induction establishes the dorsoventral polarity of the future mesoderm and the entire embryo along an axis that is set initially by cytoplasmic movements shortly after fertilization (for re-
A

Figure 6. (A) Kinetics of induction of Xlim-1 and Mix.1 in animal explants by 50 pM activin $A$. $(B)$ Kinetics of induction of Xlim- 1 by $10 \mu \mathrm{M}$ RA and activin $(50 \mathrm{pM})$ plus RA; two data points with activin alone show that the peak expression of $X \lim -1$ in this experiment occurred at $4 \mathrm{hr}$, as shown in $A$. $A$ and $B$ are different experiments. The expression of the marker gene $\mathrm{EF}-1 \alpha$ increases continuously with incubation time.

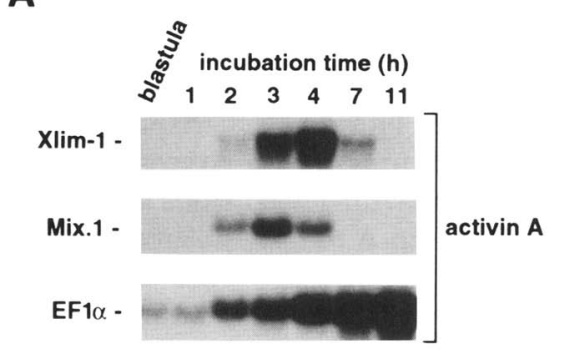

B

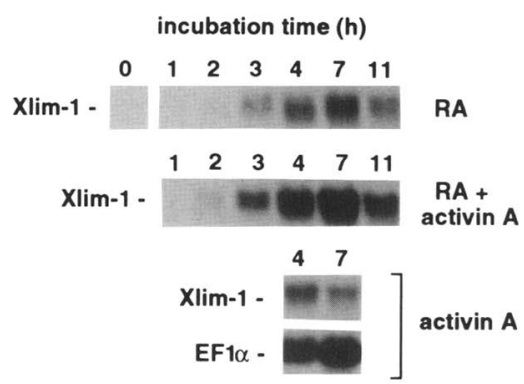




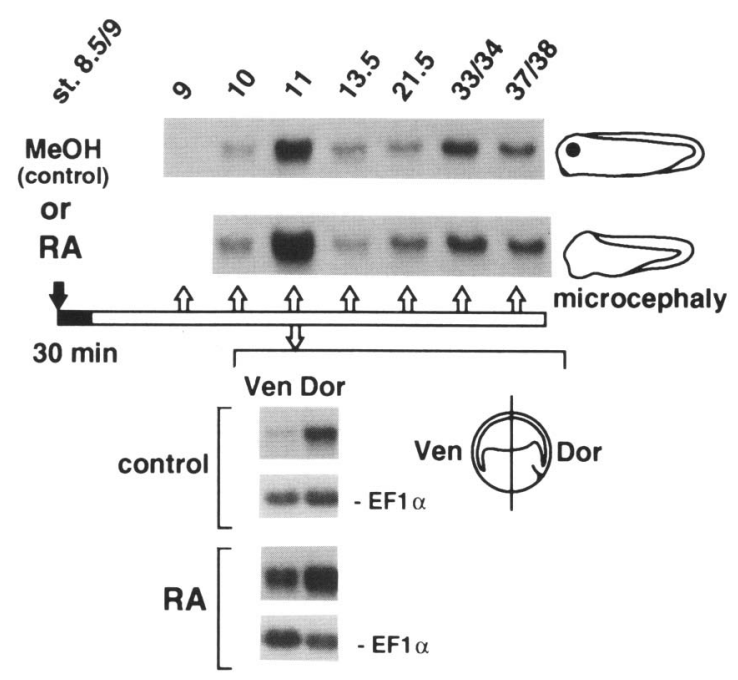

Figure 7. Expression of Xlim-1 in RA-treated embryos. Embryos at stage $8.5-9$ were exposed to $10 \mu \mathrm{M}$ RA for $30 \mathrm{~min}$, as described (Durston et al. 1989). Total RNA was extracted at various stages and analyzed for Xlim-1 RNA. At stage 11 some of the embryos were dissected into dorsal and ventral halves and $5 \mu \mathrm{g}$ of total RNA was analyzed. Blotting with $E F-1 \alpha$ probe showed that equal amounts of dorsal and ventral RNA were loaded onto the gel.

view, see Nieuwkoop 1973; Gerhart et al. 1989; Smith 1989; Dawid et al. 1990). The induction of the neural plate and establishment of the anteroposterior axis proceed during gastrulation largely under the control of the dorsal lip and the dorsal mesoderm. Although different regions of gastrula or blastula ectoderm have different competence to respond to induction (Sharpe et al. 1987; Dixon and Kintner 1989; Sive et al. 1989; Otte et al. 1991; Sokol and Melton 1991), the primary role in determining the anterior-to-posterior differentiation of the neural plate is believed to be assumed by the mesoderm (Mangold 1933; Sharpe and Gurdon 1990). It is not known how the mesoderm and the ectoderm interact during neural differentiation as no signal-transmitting molecule has been discovered, but the involvement of diffusible substances is implied by transfilter experiments (Toivonen et al. 1975). If the advancing mesoderm has a major role in patterning the neural plate, it must rapidly differentiate, by itself, during gastrulation to generate distinct signals to the overlying ectoderm. This expectation for patterning within the dorsal mesoderm contrasts with the fact that it shows no overt cytological differentiation. On the basis of abundant examples in the Drosophila embryo one may expect that the expression of regulatory genes, in particular homeo box genes, may form a pattern within the mesoderm that can be visualized only by the application of suitable probes. The Xlim-1 gene, and other homeo box genes expressed in the organizer region (Blumberg et al. 1991), may have a role in this rapid patterning of the mesoderm along the anteroposterior axis. This suggestion is supported by the pattern of expression of Xlim-1: Transcripts of this gene are first localized in the dorsal lip and the mesoderm immediately above it (Fig. 4A,B), but a short time later peak expression has moved to the anterior region of the advancing mesoderm (Fig. 4C,D).

How could the regionally distinct expression of a homeo box gene, whose protein product may be expected to be localized in the nucleus, affect the differentiation of a neighboring tissue? Clearly, the effect must be indirect. An excellent example for such interactions has been reported by Reuter et al. (1990) and Panganiban et al. (1990). In the formation of the midgut in Drosophila the expression of the $d p p$ gene, which encodes a growth factor related to TGF- $\beta$, is regulated by the homeo box genes $U b x$ and $a b d A$. In the mesoderm of the middle region, $U b x$ activates $d p p$, whose product translocates to the endoderm where it activates another homeo box gene, labial. In more posterior mesoderm the activity of $a b d A$ represses both $U b x$ and $d p p$, and labial is not expressed in the endoderm. Genetic evidence clearly demonstrated that appropriate expression of these genes /and others, omitted here) is required for midgut morphogenesis. A similar network of regulatory interactions may operate in the amphibian gastrula during neural induction; the Xlim-1 gene is expected to be one of the participants in this network.

\section{The role of $R A$ in patterning during gastrulation}

RA has profound effects on a variety of biological systems. When added to Xenopus embryos it inhibits head development (Durston et al. 1989), implying a role as a posterior determinant in embryogenesis. This idea has received support from different experiments. Animal explants induced to form dorsal mesoderm by activin become more ventral if also treated with RA (Ruiz i Altaba and Jessel 1991a). Likewise, gastrula ectoderm induced to form anterior structures (e.g., cement gland) is converted to more posterior cell types by exposure to RA (Sive et al. 1990). Finally, XlHbox 6, a posteriorly expressed homeo box gene, is not inducible by RA and weakly inducible by activin but synergistically induced by activin plus RA (Cho and De Robertis 1990). The overall conclusion of these studies has been that RA affects cells that are specified as mesoderm by turning them into a ventral direction that, in subsequent differentiation, corresponds to enhancing posterior or suppressing anterior development, or both. To exert this ventralizing effect in normal embryogenesis, a ventrally localized source of RA in the gastrula has been postulated (Ruiz i Altaba and Jessel 1991a).

Our results raise some questions regarding the above interpretation. The Xlim-1 gene is expressed in an extreme dorsal pattern in the gastrula (Fig. 4), and it is nevertheless induced in animal explants by RA, either alone or in synergy with activin (Fig. 5A). Furthermore, RA-treated embryos overexpress Xlim-1 RNA at the gastrula stage (Fig. 7). Thus, RA enhances the expression of at least one dorsal marker in the frog gastrula, just as it enhances some (XlHbox 6; Cho and De Robertis 1990) but not all (Xhox 3; Ruiz i Altaba and Jessel 1991a) pos- 
terior markers. Nevertheless, the biological effects of RA in the amphibian embryo are certainly ventralizing and posterior enhancing, both when applied early as in our experiments (Durston et al. 1989; Ruiz i Altaba and Jessel 1991a), or later when the effect is mostly on brain development (Ruiz i Altaba and Jessel 1991b; Sharpe 1991). A resolution of this apparent contradiction might come from determining whether RA effects seen in explant or whole embryo experiments represent in vivo functions of this molecule. Also, it will be important to determine which RA effects are direct. Finally, although the presence of RA in the embryo is established (Durston et al. 1989), its distribution is not. Direct measurements of RA localization are technically difficult; an indirect approach is to use an indicator gene that responds to RA. It is possible that Xlim-1 is such an indicator gene. If the localization of Xlim-1 and Mix.1 in vivo in the gastrula and their responses in explant experiments were taken as guides to the distribution of activin and RA in the embryo, it would follow that activin is present in the entire vegetal hemisphere, and RA in the dorsovegetal region. If RA were present in the ventrovegetal region, the Xlim-1 gene should be activated there because it does respond in this region to exogenously added RA (Fig. 7). At least one isoform of the RA receptor is expressed during Xenopus embryogenesis (Ellinger-Ziegelbauer and Dreyer 1991), but its distribution does not give any direct indication to the possible role of RA in early development.

\section{Materials and methods}

\section{PCR cloning of fragments from Xlim homeo box genes}

PCR amplification with degenerate primers (Saiki et al 1988; Gould et al. 1989) was performed in $100 \mu \mathrm{l}$ of $10 \mathrm{mM}$ Tris- $\mathrm{Cl}$ (pH 8.3), $50 \mathrm{~mm} \mathrm{KCl}, 2 \mathrm{mM} \mathrm{MgCl}, 0.01 \%$ gelatin, $0.2 \mathrm{mM}$ each of dATP, dGTP, dCTP, and TTP, $10 \mathrm{ng} / \mu \mathrm{l}$ each of oligonucleotides, $2.5 \mathrm{ng} / \mu \mathrm{l}$ DNA from cDNA libraries prepared from stage 13/14 and stage 24/25 Xenopus embryos (Richter et al. 1988), and $0.025 \mathrm{U} / \mu \mathrm{l}$ of $\mathrm{Taq}$ polymerase. The reaction cycles were $\left(94^{\circ} \mathrm{C}, 1 \mathrm{~min} ; 37^{\circ} \mathrm{C}, 2 \mathrm{~min} ; 65^{\circ} \mathrm{C}, 1 \mathrm{~min}\right) \times 2$, and $\left(94^{\circ} \mathrm{C}, 1 \mathrm{~min}\right.$; $\left.50^{\circ} \mathrm{C}, 1 \mathrm{~min} ; 72^{\circ} \mathrm{C}, 1 \mathrm{~min}\right) \times 30$. The following oligonucleotide primers were used (see also Fig. 1C): CCGGATCC(C/A)G(A/ G)GGACC(T/A)/C/A)G(A/G)ACNACNAT (primer A, sense strand corresponding to RGPRTTI plus BamHI linker), and CCGTCGAC(T/C)TC(T/C)TTAGACCGCCG(A/G)TT/T/C)TG(A/G)AACCA (primer B, antisense strand corresponding to WFQNRRSKE plus SalI linker). The amplified 0.18 -kb band was purified from an agarose gel, and the ends were filled with Klenow fragment, digested with BamHI and SalI, and cloned into the BamHI and Sall sites of pBluescript KS(+) (Stratagene). Recombinant clones were screened by colony hybridization using the purified $0.18-\mathrm{kb}$ fragment labeled with $\left[\alpha^{-32} \mathrm{P}\right] \mathrm{dCTP}$ and primers $\mathrm{A}$ and $\mathrm{B}$. Hybridization was performed in $0.5 \mathrm{M}$ sodium phosphate buffer (pH 7.0), 1 mM EDTA, $1 \%$ bovine serum albumin, $7 \%$ SDS (Church and Gilbert 1984), at $65^{\circ} \mathrm{C}$ for $12-16 \mathrm{hr}$. Filters were washed in $2 \times$ SSPE [ $1 \times$ SSPE is $0.01 \mathrm{M}$ sodium phosphate buffer (pH 7.0), $0.15 \mathrm{M} \mathrm{NaCl}, 0.6 \mathrm{mM}$ EDTA] and $0.1 \%$ SDS at $65^{\circ} \mathrm{C}$. Some recombinant clones were subjected to PCR reaction using primers $A$ and $B$ to obtain DNA fragments to be used as hybridization probes after labeling with $\left[\alpha^{-32} \mathrm{P}\right] \mathrm{dCTP}$ and primers A and B.

Embryonic cDNA libraries in $\lambda$ gt11 (Richter et al. 1988) were screened with inserts from different clones labeled as described above. Twenty clones of Xlim-1 were isolated from $\sim 1.4 \times 10^{6}$ plaques of the stage $13 / 14$ and $24 / 25$ libraries, and the inserts were recloned into the EcoRI site of pBluescript KS(+). Nucleotide sequencing was performed on both strands by the using Sequenase kit with or without 7-deaza-dGTP or dITP (U.S. Biochemical). The longest of eight Xlim-1 clones that were characterized, pXH32 $(3.1 \mathrm{~kb})$, was used for further analysis.

\section{RNA blotting}

Probe DNAs for hybridization analysis were generated by PCR amplification using recombinant plasmid and KS/SK primers (Stratagene). The entire Xlim-1 cDNA clone (Fig. 1B) was used as a probe. DNA was labeled by multiprimed labeling with $\left[\alpha-{ }^{32} \mathrm{P}\right] \mathrm{dCTP}$.

Total RNA was extracted from tissues of adult frogs and embryos by the acid guanidinium thiocyanate/phenol/chloroform method (Chomczynski and Sacchi 1987) or the guanidinium thiocyanate/phenol method (Sargent et al. 1986). RNA samples $(5-10 \mu \mathrm{g})$ were electrophoresed in $1 \%$ agarose/formaldehyde or $1.1 \%$ agarose/glyoxal gels (Thomas 1983), blotted onto nylon filters, and hybridized as described by Church and Gilbert (1984).

\section{Induction experiments}

Induction experiments were carried out as described previously (Rosa et al. 1988). Animal explants were dissected at stage 8-9 (Nieuwkoop and Faber 1967) and cultured in the presence of different factors for times given in the figure legends. The following growth factors were used: human recombinant activin $A$, (provided by Genentech) TGF- $\beta 2$ (from R\&D Sytems); recombinant TGF- $\beta 3$ (provided by A. Roberts) (Roberts et al. 1990); and basic FGF (from AMGEN Biochemicals).

\section{Whole-mount in situ hybridization}

Hybridization experiments followed the method described by Hemmati-Brivanlou et al. (1990) and Harland (1991). Embryos derived from albino females were used. Digoxigenin-labeled RNAs were prepared by in vitro transcription of Xhol- or BamHI-digested pXH32 for antisense or sense strand probes, respectively, with the use of an RNA-labeling kit (Boehringer Mannheim). Antidigoxigenin antibodies (Fab fragment) conjugated with alkaline phosphatase were from Boehringer Mannheim.

\section{Acknowledgments}

We thank Martha Rebbert for assisting in some experiments, Drs. H. Robert Horvitz, Ding Xue, Martin Chalfie, Thomas R. Bürglin, and Gary Ruvkun for unpublished information, and Genentech, Inc., particularly Dr. R. Schwall, for recombinant activin $\mathrm{A}$.

The publication costs of this article were defrayed in part by payment of page charges. This article must therefore be hereby marked "advertisement" in accordance with 18 USC section 1734 solely to indicate this fact.

\section{References}

Asashima, M., H. Nakano, K. Shimada, K. Kinoshita, K. Ishii, H. Shibai, and N. Ueno. 1990. Mesodermal induction in early 
amphibian embryos by activin A lerythroid differentiation factor). Wilhelm Roux's Arch. Dev. Biol. 198: 330-335.

Birkenmeier, E.H. and J.I. Gordon. 1986. Developmental regulation of a gene that encodes a cysteine-rich intestinal protein and maps near the murine immunoglobulin heavy chain locus. Proc. Natl. Acad. Sci. 83: 2516-2520.

Blumberg, B., C.V.E. Wright, E.M. De Robertis, and K.W.Y. Cho. 1991. Organizer-specific homeobox genes in Xenopus laevis embryos. Science 253: 194-196.

Boehm, T., L. Foroni, M. Kennedy, and T.H. Rabbitts. 1990. The rhombotin gene belongs to a class of transcriptional regulators with a potential novel protein dimerization motif. Oncogene 5: 1103-1105.

Bopp, D., M. Burri, S. Baumgartner, G. Frigerio, and M. Noll. 1986. Conservation of a large protein domain in the segmentation gene paired and in functionally related genes of Drosophila. Cell 47: 1033-1040.

Bürglin, T.R., M. Finney, A. Coulson, and G. Ruvkun. 1989. Caenorhabditis elegans has scores of homeobox-containing genes. Nature 341: 239-243.

Cho, K.W.Y. and E.M. De Robertis. 1990. Differential activation of Xenopus homeo box genes by mesoderm-inducing growth factors and retinoic acid. Genes \& Dev. 4: 1910-1916.

Cho, K.W.Y., E.A. Morita, C.V.E. Wright, and E.M. De Robertis. 1991. Overexpression of a homeodomain protein confers axis-forming activity to uncommitted Xenopus embryonic cells. Cell 65: 55-64.

Chomczynski, P. and N. Sacchi. 1987. Single-step method of RNA isolation by acid guanidinium thiocyanate-phenolchloroform extraction. Anal. Biochem. 162: 156-159.

Church, G.M. and W. Gilbert 1984. Genomic sequencing. Proc. Natl. Acad. Sci. 81: 1991-1995.

Dawid, I.B., T.D. Sargent, and F. Rosa. 1990. The role of growth factors in embryonic induction in amphibians. Curr. Topics Devel. Biol. 24: 261-288.

De Robertis, E.M., G. Oliver, and C.V.E. Wright. 1990. Homeobox genes and the vertebrate body plan. Sci. Am. 263: 46-52.

De Robertis, E.M., E.A. Morita, and K.W.Y. Cho. 1991. Gradient fields and homeobox genes. Development 112: 669-678.

Dixon, J.E. and C.R. Kintner. 1989. Cellular contacts required for neural induction in Xenopus embryos: Evidence for two signals. Development 106: 749-757.

Durston, A.J., J.P.M. Timmermans, W.J. Hage, H.F.J. Hendriks, N.J. de Vries, M. Heideveld, and P.D. Nieuwkoop. 1989. Retinoic acid causes an anteroposterior transformation in the developing central nervous system. Nature 340: 140-144.

Ellinger-Ziegelbauer, H. and C. Dreyer. 1991. A retinoic acid receptor expressed in the early development of Xenopus laevis. Genes \& Dev. 5: 94-104.

Freyd, G., S.K. Kim, and H.R. Horvitz. 1990. Novel cystein-rich motif and homeodomain in the product of the Caenorhabditis elegans cell lineage gene lin-11. Nature 344: 876-879.

Gerhart, J., M. Danilchik, T. Doniach, S. Roberts, B. Rowning, and R. Stewart. 1989. Cortical rotation of the Xenopus egg: Consequences for the anteroposterior pattern of embryonic dorsal development. Development (Suppl.) 107: 37-51.

Good, P.J., K. Richter, and I.B. Dawid. 1990. A nervous systemspecific isotype of the $\beta$-subunit of $\mathrm{Na}^{+}, \mathrm{K}^{+}$-ATPase expressed during early development of Xenopus laevis. Proc. Natl. Acad. Sci. 87: 9088-9092.

Gould, S.J., S. Subramani, and I. E. Scheffler. 1989. Use of the DNA polymerase chain reaction for homology probing: Isolation of partial cDNA or genomic clones encoding the ironsulfur protein of succinate dehydrogenase from several species. Proc. Natl. Acad. Sci. 86: 1934-1938.
Harland, R.M. 1991. In situ hybridization: An improved whole mount method for Xenopus embryos. Methods Cell Biol. 36: 685-695.

Hemmati-Brivanlou, A., D. Frank, M.E. Bolce, B.D. Brown, H.L. Sive, and R.M. Harland. 1990. Localization of specific mRNAs in Xenopus embryos by whole-mount in situ hybridization. Development 110: 325-330.

Herr, W., R.A. Sturm, R.G. Clerc, L.M. Corcoran, D. Baltimore, P.A. Sharp, H.A. Ingraham, M.G. Rosenfeld, M. Finney, G. Ruvkun, and H.R. Horvitz. 1988. The POU domain: A large conserved region in the mammalian pit-1, oct-1, oct-2, and Caenorhabditis elegans unc-86 gene products. Genes \& Dev. 2: 1513-1516.

Karlsson, O., S. Thor, T. Norberg, H. Ohlsson, and T. Edlund. 1990. Insulin gene enhancer binding protein Isl-1 is a member of a novel class of proteins containing both a homeo- and a cys-his domain. Nature 344: 879-882.

Kessel, M. and P. Gruss. 1990. Murine developmental control genes. Science 249: 374-379.

Kimelman, D. and M. Kirschner. 1987. Synergistic induction of mesoderm by FGF and TGF-beta and the identification of an mRNA coding for FGF in the early Xenopus embryo. Cell 51: 869-877.

Krieg, P.A., S.M. Varnum, W.M. Wormington, and D.A. Melton. 1989. The mRNA encoding elongation factor $1-\alpha(E F-1 \alpha)$ is a major transcript at the midblastula transition in Xenopus. Dev. Biol. 133: 93-100.

Li, P.M., I. Reichert, G. Freyd, H.R. Horvitz, and C.T. Walsh. 1991. The LIM region of a presumptive Caenorhabditis elegans transcription factor is an iron-sulfur- and zinc-containing metalloprotein. Proc. Natl. Acad. Sci. 88: 9210-9213.

Liebhaber, S.A., J.G. Emery, M. Urbanek, X. Wand, and N.E. Cooke. 1990. Characterization of a human cDNA encoding a widely expressed and highly conserved cysteine-rich protein with an unusual zinc-finger motif. Nucleic Acids Res. 18: 3871-3879.

Lonai, P. and A. Orr-Urtreger. 1990. Homeogenes in mammalian development and the evolution of the cranium and central nervous system. FASEB /. 4: 1436-1443.

Melton, D.A. 1991. Pattern formation during animal development. Science 252: 234-241.

Mangold, O. 1933. Über die Induktionsfähigkeit der verschiedenen Bezirke der Neurula von Urodelen. Naturwissenschaften 21: 761-766.

McGuire, E.A., R.D. Hockett, K.M. Pollock, M.F. Bartholdi, S.J. O'Brien, and S.J. Korsmeyer. 1989. The $t(11 ; 14)(\mathrm{p} 15 ; \mathrm{ql} 1)$ in a T-cell acute lymphoblastic leukemia cell line activates multiple transcripts, including Ttg-1, a gene encoding a potential zinc finger protein. Mol. Cell. Biol. 9: 2124-2132.

Newport, J., and M. Kirschner. 1982. A major developmental transition in early Xenopus embryos. I. Characterization and timing of cellular changes at the midblastula stage. Cell 30: $675-686$

Nieuwkoop, P.D. 1973. The "organization center" of the amphibian embryo: Its origin, spatial organization, and morphogenetic action. Adv. Morphogenet. 10: 1-39.

Nieuwkoop, P.D. and J. Faber. 1967. Normal table of Xenopus laevis (Daudin). North Holland, Amsterdam.

Otte, A.P., I.M. Kramer, and A.J. Durston. 1991. Protein kinase $\mathrm{C}$ and regulation of the local competence of Xenopus ectoderm. Science 251: 570-573.

Panganiban, G.E.F., R. Reuter, M.P. Scott, and F. M. Hoffmann. 1990. A Drosophila growth factor homolog, decapentaplegic, regulates homeotic gene expression within and across germ layers during midgut morphogenesis. Development 110: 1041-1050. 
Reuter, R., G.E.F. Panganiban, F.M. Hoffmann, and M.P. Scott. 1990. Homeotic genes regulate the spatial expression of putative growth factors in the visceral mesoderm of Drosophila embryos. Development 110: 1031-1040.

Richter, K., H. Grunz, and I.B. Dawid. 1988. Gene expression in the embryonic nervous system of Xenopus laevis. Proc. Natl. Acad. Sci. 85: 8086-8090.

Roberts, A.B., P. Kondaiah, F. Rosa, S. Watanabe, P. Good, D. Danielpour, N.S. Roche, M.L. Rebbert, I.B. Dawid, and M.B. Sporn. 1990. Mesoderm induction in Xenopus laevis distinguishes between the various TGF- $\beta$ isoforms. Growth Factors 3: 277-286.

Rosa, F.M. and I.B. Dawid. 1990. Molecular studies on embryonic induction. UCLA Symp. Dev. Biol. 125: 163-174.

Rosa, F.M. 1989. Mix.1, an homeobox mRNA inducible by mesoderm inducers, is expressed mostly in the presumptive endodermal cells of Xenopus embryos. Cell 57: 965-974.

Rosa, F., A.B. Roberts, D. Danielpour, L.L. Dart, M.B. Sporn, and I.B. Dawid. 1988. Mesoderm induction in amphibians: The role of TGF- $\beta 2$-like factors. Science 239: 783-785.

Ruiz i Altaba, A. and T. Jessell. 1991a. Retinoic acid modifies mesodermal patterning in early Xenopus embryos. Genes \& Dev. 5: 175-187.

- 1991b. Retinoic acid modifies the pattern of cell differentiation in the central nervous system of neurula stage $X e$ nopus embryos. Development 112: 945-958.

Ruiz i Altaba, A. and D.A. Melton. 1989a. Interaction between peptide growth factors and homeobox genes in the establishment of antero-posterior polarity in frog embryos. Nature 341: 33-38.

-1989b. Involvement of the Xenopus homeobox gene $\mathrm{Xhox} 3$ in pattern formation along the anterior-posterior axis. Cell 57: 317-326.

Ruvkun, G. and M. Finney. 1991. Regulation of transcription and cell identity by POU domain proteins. Cell 64: 475-478.

Saiki, R.K., D.H. Gelfand, S. Stoffel, S.J. Scharf, R. Higuchi, G.T. Horn, K.B. Mullis, and H.A. Ehrlich. 1988. Primer-directed enzymatic amplification of DNA with a thermostable DNA polymerase. Science 239: 487-491.

Sargent, T.D., M. Jamrich, and I.B. Dawid. 1986. Cell interactions and the control of gene activity during early development of Xenopus laevis. Dev. Biol. 114: 238-246.

Scott, M.P., J.W. Tamkun, and G.W. Hartzell III. 1989. The structure and function of the homeodomain. Biochim. Biophys. Acta 989: 25-48.

Sharpe, C.R. 1991. Retinoic acid can mimic endogenous signals involved in transformation of the Xenopus nervous system. Neuron 7: 239-247.

Sharpe, C.R. and J.B. Gurdon. 1990. The induction of anterior and posterior neural genes in Xenopus laevis. Development 109: 765-774.

Sharpe, C.R., A. Fritz, E.M. De Robertis, and J.B. Gurdon. 1987. A homeobox-containing marker of posterior neural differentiation shows the importance of predetermination in neural induction. Cell 50: 749-758.

Sive, H.L. and P.F. Cheng. 1991. Retinoic acid perturbs the expression of Xhox.lab genes and alters mesodermal determination in Xenopus laevis. Genes \& Dev. 5: 1321-1332.

Sive, H.L., K. Hattori, and H. Weintraub. 1989. Progressive determination during formation of the anteroposterior axis in Xenopus laevis. Cell 58: 171-180.

Sive, H.L., B.W. Draper, R.M. Harland, and H. Weintraub. 1990. Identification of a retinoic acid-sensitive period during primary axis formation in Xenopus laevis. Genes \& Dev. 4: 932-942.

Slack, J.M.W., B.G. Darlington, J.K. Heath, and S.F. Godsave.
1987. Mesoderm induction in early Xenopus embryos by heparin-binding growth factors. Nature 326: 197-200.

Smith, J.C. 1989. Mesoderm induction and mesoderm-inducing factors in early amphibian development. Development 105: 665-677.

Smith, J.C., B.M.J. Price, K. Van Nimmen, and D. Huylebroeck. 1990. Identification of a potent Xenopus mesoderm-inducing factor as a homologue of activin A. Nature 345: 729-731.

Sokol, S. and D.A. Melton. 1991. Pre-existent pattern in Xenopus animal pole cells revealed by induction with activin. Nature 351: 409-411.

Spemann, H. and H. Mangold. 1924. Über Induktion von Embryonalanlagen durch Implantation artfremder Organisatoren. Wilhelm Roux's Arch. Entwicklungsmech. Org. 100: 599-638.

Thiébaud, C.H. and M. Fischberg. 1977. DNA content in the genus Xenopus. Chromosoma 59: 253-257.

Thomas, P.S. 1983. Hybridization of denatured RNA transferred or dotted to nitrocellulose paper. Methods Enzymol. 100: $255-266$.

Thomsen, G., T. Woolf, M. Whitman, S. Sokol, J. Vaughan, W. Vale, and D.A. Melton. 1990. Activins are expressed early in Xenopus embryogenesis and can induce axial mesoderm and anterior structures. Cell 63: 485-493.

Toivonen, S., D. Tarin, L. Saxén, P.J. Tarin, and J. Wartiovaara. 1975. Transfilter studies on neural induction in the newt. Differentiation 4: 1-7.

Treisman, J., E. Harris, and C. Desplan. 1991. The paired box encodes a second DNA-binding domain in the paired homeo domain protein. Genes \& Dev. 5: 594-604.

Way, J.C. and M. Chalfie. 1988. mec-3, a homeobox-containing gene that specifies differentiation of the touch receptor neurons in C. elegans. Cell 54: 5-16.

Wilkinson, D.G. and R. Krumlauf. 1990. Molecular approaches to the segmentation of the hindbrain. Trends Neurosci. 13: 335-339. 


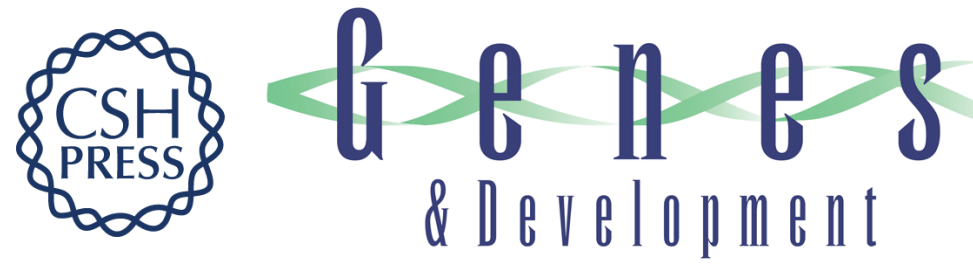

\section{The LIM domain-containing homeo box gene Xlim-1 is expressed specifically in the organizer region of Xenopus gastrula embryos.}

M Taira, M Jamrich, P J Good, et al.

Genes Dev. 1992, 6:

Access the most recent version at doi:10.1101/gad.6.3.356

References This article cites 69 articles, 28 of which can be accessed free at:

http://genesdev.cshlp.org/content/6/3/356.full.html\#ref-list-1

License

Email Alerting

Service

Receive free email alerts when new articles cite this article - sign up in the box at the top right corner of the article or click here.

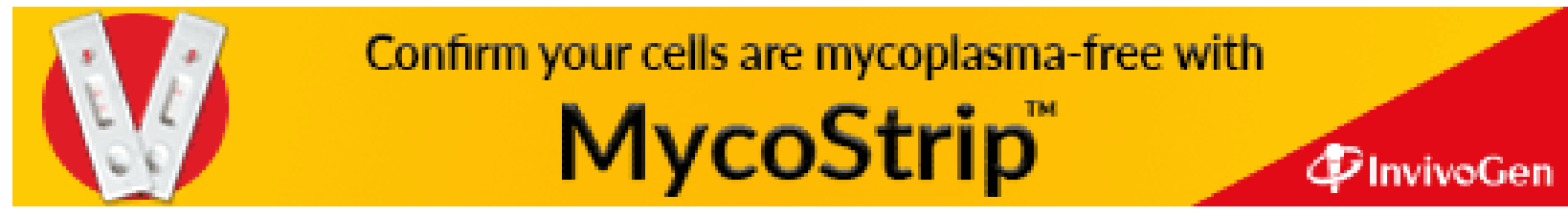

